\begin{tabular}{|l|l|}
\hline SITAS & $\begin{array}{l}\text { JANHUS Journal of Animal Husbandry Science } \\
\text { Jurnal Ilmu Peternakan } \\
\text { Fakultas Pertanian, Universitas Garut } \\
\text { P ISSN : 2548-7914, E ISSN : 2775-0469 }\end{array}$ \\
\hline
\end{tabular}

\title{
ANALISIS FAKTOR PENDORONG MINAT MASYARAKAT TERHADAP USAHA PETERNAKAN AYAM BROILER DENGAN POLA KEMITRAAN DI KECAMATAN KARANGPAWITAN KABUPATEN GARUT
}

\section{(Analysis of Driving Factors of Public Interest in Broiler Chicken Livestock Business in Karangpawitan Garut)}

\author{
Dewi Maryani ${ }^{1}$; Ervi Herawati ${ }^{2}$; Tendy Kusmayadi ${ }^{3}$; Tati Rohayati ${ }^{4}$; \\ Titin Nurhayatin ${ }^{5}$ \\ ${ }^{1}$ Alumni Program Studi Peternakan, Fakultas Pertanian, Universitas Garut
$2,3,4,5$ Program Studi Peternakan, Fakultas Pertanian, Universitas Garut
}

Email:

1dewimarya81@gmail.com

2erviherawati@uniga.ac.id

3tendykusmayadi@uniga.ac.id

\begin{abstract}
Abstrak
Peternakan ayam broiler merupakan salah satu usaha peternakan yang memberikan kontribusi terbanyak dalam memenuhi kebutuhan pangan hewani di Indonesia, yang paling utama adalah meningkatkan pendapatan. Penelitian ini bertujuan untuk menganalisis minat masyarakat terhadap usaha peternakan ayam broiler dengan pola kemitraan di Kecamatan Karangpawitan Kabupaten Garut, yang dilakukan pada bulan April 2020. Metode penelitian yang digunakan adalah metode sensus, dengan jumlah responden sebanyak 30 peternak. Teknik pengumpulan data yang digunakan adalah kuesioner, dengan jenis data dikuantitatifkan. Pengukuran minat masyarakat dalam beternak ayam broiler dengan menggunakan skala Liekert. Hasil penelitian yang diperoleh menunjukkan bahwa faktor-faktor yang mempengaruhi minat masyarakat terhadap usaha ayam broiler di Kecamatan Karangpawitan Kabupaten Garut adalah modal (puas); jaminan pasar (sangat puas); jaminan harga dan nilai ekonomis (sangat puas). Faktor yang paling berpengaruh adalah jaminan harga.
\end{abstract}

Kata kunci: analisis, minat masyarakat, pola kemitraan, ayam broiler.

\begin{abstract}
Broiler chicken farm is one of the livestock businesses that provides the largest contribution in meeting the needs of animal food in Indonesia, the main thing is to increase income. This study aims to analyze the public interest in broiler chicken farming with a partnership pattern in Karangpawitan Garut conducted in April 2020. The research method used is the census method, with the number of respondents as many as 30 breeders. The data collection technique used was a questionnaire, with quantitative data types. Measurement of public interest in raising broiler chickens using the Liekert scale. The results obtained indicate that
\end{abstract}




\begin{abstract}
the factors that influence public interest in broiler chicken business in Karangpawitan Garut are capital (satisfied); market guarantee (very satisfied); price and economic value guarantee (very satisfied). The most influential factor is the price guarantee.
\end{abstract}

Keywords: analysis, public interest, partnership patterns, broiler chickens.

\title{
1 Pendahuluan
}

Usaha peternakan merupakan kegiatan yang sudah lama berkembang dimasyarakat. Selain untuk memenuhi kebutuhan protein hewani, yang paling utama adalah meningkatkan pendapatan. Salah satu jenis ternak yang banyak dipelihara dimasyarakat adalah ayam broiler karena kemampuannya sebagai penghasil daging yang potensial. Hal ini didukung oleh pendapat Arifin (2004), Ayam broiler merupakan salah satu komoditas ternak yang tumbuh cepat terutama dalam produksi. Usaha peternakan ayam broiler merupakan salah satu usaha peternakan yang memberikan kontribusi terbanyak dalam memenuhi kebutuhan pangan hewani di Indonesia. Berdasarkan data statistik peternakan, pada tahun 1970 kontribusi daging unggas hanya sebesar 15\%, tetapi pada tahun 2017 produksi telah mencapai 2,1 ton atau 66,34\% terhadap produksi daging secara kesuluruhan. Usaha ternak ayam ras pedaging di Indonesia mengalami peningkatan dari tahun ke tahun, pada tahun 2013 sebanyak 1.344.191.000 ekor, dan pada tahun 2017 meningkat menjadi sebanyak 1.698.368.000 ekor (Badan Pusat Stastistik Indonesia, 2018).

Berkembangnya usaha ternak ayam broiler di Kabupaten Garut bermula dari peternakan yang dikelola secara mandiri dengan skala kecil yang tujuannya hanya digunakan untuk pemenuhan kebutuhan keluarga. Seiring dengan berkembangnya teknologi dan tuntutan ekonomi, usaha ternak ayam broiler mulai dikembangkan dari skala menengah sampai skala besar. Pada saat peternak telah memiliki usaha ternak dengan skala yang lebih besar mulai timbul masalahmasalah antara lain distribusi DOC dan pakan yang kurang lancar, hal tersebut akan mempengaruhi waktu dan masa berproduksi ayam broiler dan menyebabkan biaya produksi yang dikeluarkan akan lebih besar. Selain itu ketika panen, harga ayam broiler sangat fluktuatif sehingga peternak sering mengalami kerugian jika harga jual rendah dan akhirnya peternak memutuskan untuk menggunakan pola kemitraan.

Pola kemitraan adalah salah satu konsep yang sudah banyak dikenal. Dalam pola kemitraan ini diharapkan suatu lembaga mampu berfungsi sebagai penampung aspirasi para anggota kemitraan tersebut (Rudiyanto, 2014). Pola kemitraan dilakukan peternak dengan cara menjalin kerjasama atau bermitra dengan perusahaan penyedia sarana produksi, dengan ketentuan peternak diharuskan menjual semua hasil produksinya kepada perusahaan inti sesuai dengan harga kesepakatan yang tertera dalam kontrak yang telah disepakati bersama oleh peternak dan perusahaan yang bersangkutan. Kontrak kerjasama tersebut berisi mengenai, perusahaan berperan sebagai inti dan peternak berperan sebagai plasma (Windarsari, 2012).

Pola kemitraan ayam broiler dimana peternak sebagai plasma dan perusahaan sebagai inti, dalam pola kemitraan tersebut inti menjamin kelancaran dalam distribusi DOC dan pakan serta kesepakatan harga jual panen. Namun demikian kadang harga kesepakatan yang dibuat lebih rendah dari harga dipasaran, sehingga berpengaruh terhadap pendapatan peternak. Pendapatan yang diperoleh peternak merupakan selisih antara penerimaan yang diperoleh dikurangi dengan total biaya yang dikeluarkan. Pendaptan yang diperoleh peternak akan berbeda-beda sesuai dengan tingkat kemampuan peternak itu sendiri dalam mengalokasikan faktor-faktor yang dimilikinya. Faktor-faktor tersebut diantaranya adalah jumlah DOC, pakan, tenaga kerja, vaksin, obat, vitamin, pemanas dan mortalitas. Peternak harus mampu mengelola faktor-faktor produksi 
tersebut sehingga dapat dicapai produksi yang maksimal. Menurut Raharjo (2018), kemitraan adalah jalinan kerjasama usaha yang merupakan strategi bisnis yang dilakukan antara dua pihak atau lebih dengan prinsip saling membutuhkan, saling memperbesar dan saling menguntungkan.

Kecamatan Karangpawitan merupakan wilayah dengan jumlah peternak ayam broiler terbanyak yaitu 30 peternak. Peternak tersebut merupakan peternak yang melakukan usaha ternaknya dengan pola kemitraan. Dengan adanya pola kemitraan, para peternak sangat terbantu dan antusias dalam melakukan usahanya. Pola kemitraan ini membantu peternak yang memiliki modal minim dan strategi pemasaran yang kurang dipahami untuk tetap dapat melakukan kegiatan usahanya dengan maksimal. Oleh karena itu "Analisis Faktor Pendorong Minat Masyarakat terhadap Usaha Peternakan Ayam Broiler dengan Pola Kemitraan di Kecamatan Karangpawitan Kabupaten Garut" perlu di kaji.

\section{$2 \quad$ Metodologi}

\subsection{Waktu dan Tempat}

Penelitian ini dilaksanakan pada bulan Maret sampai dengan April 2020 yang bertempat di Kecamatan Karangpawitan Kabupaten Garut.

\subsection{Objek Penelitian}

Objek penelitian ini adalah peternak ayam broiler yang merupakan penduduk berdomisili di wilayah Kecamatan Karangpawitan Kabupaten Garut dengan responden sebanyak 30 orang peternak.

\subsection{Metode Penelitian}

Metode yang digunakan dalam penelitian ini adalah metode sensus yakni kegiatan mengumpulkan data dan informasi dengan cara mengamati seluruh elemen dari populasi. Dari hasil pengamatan dapat diperoleh karakteristik populasi yaitu berupa ukuran-ukuran yang disebut dengan parameter yang sumber data dan informasi utamanya diperoleh dari responden. Semua populasi dijadikan sebagai bahan penelitian dengan menggunakan kuesioner sebagai instrumen pengumpulan datanya.

\subsection{Analisis Data}

Analisa data yang digunakan pada penelitian ini adalah analisa statistika deskriptif dengan menggunakan pengelompokan, penyederhanaan, dan penyajian data. Pengukuran minat masyarakat dalam beternak ayam broiler menggunakan skala Liekert. Variabel penelitian diukur dengan cara menguraikan sub variabel-sub variabel variabel dalam bentuk item-item pertanyaan yang disusun dalam kuesioner dengan bobot nilai (skor) jawaban 1-5.

\section{Hasil dan Pembahasan}

\section{Minat Masyarakat}

Minat masyarakat terhadap usaha ternak ayam broiler adalah alasan masyarakat untuk memilih beternak ayam broiler di Kecamatan Karangpawitan Kabupaten Garut. Analisis minat masyarakat tersebut diukur melalui sub variabel: 


\section{a. Ketersediaan Modal, \\ b. Jaminan Pasar, \\ c. Jaminan Harga, dan \\ d. Nilai Ekonomis.}

\section{Ketersediaan Modal}

Analisis minat masyarakat terhadap usaha ternak ayam broiler dilihat berdasarkan variabel ketersediaan modal diukur dengan menggunakan sub variabel: (1) uang, (2) lahan, dan (3) sapronak. Analisis minat masyarakat terhadap usaha ternak ayam broiler dengan berdasarkan variabel ketersediaan modal dapat dilihat pada Gambar 1.

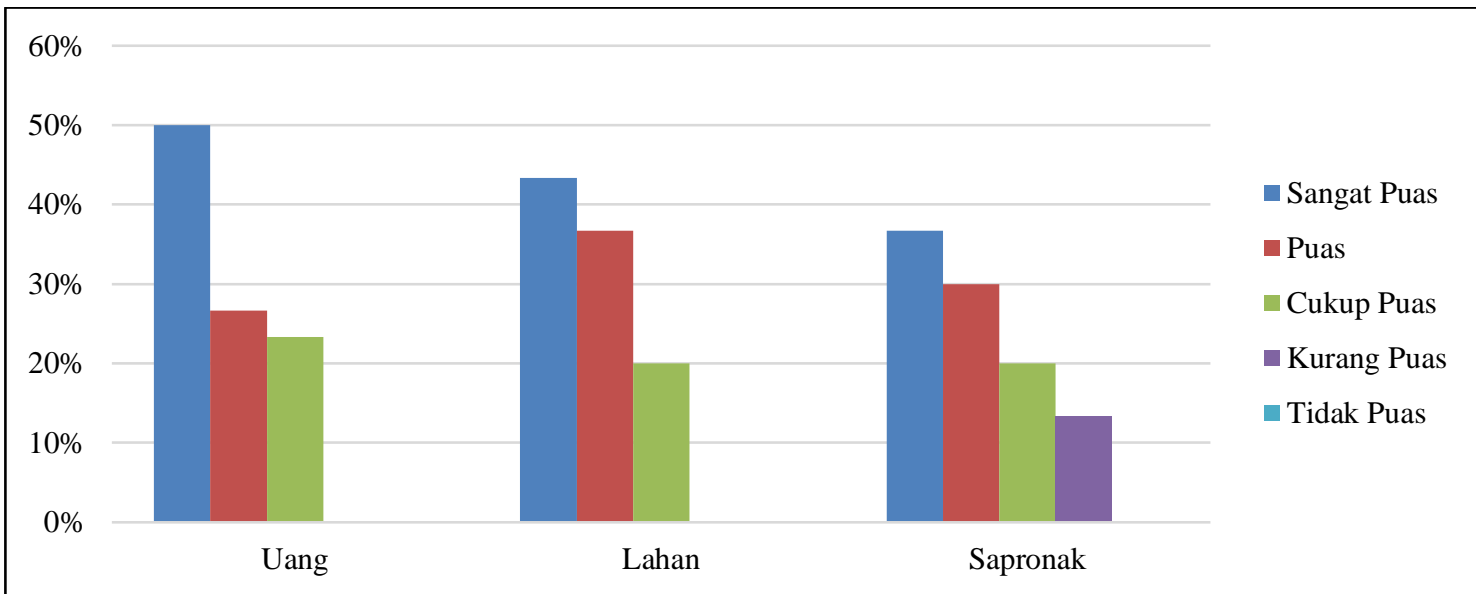

Gambar 1. Histogram Minat Masyarakat terhadap Usaha Ternak Ayam Broiler Berdasarkan Variabel Ketersediaan Modal

Gambar 1 menunjukkan uang memiliki skor tertinggi dengan persentase 50,00\% dengan kategori sangat puas. Lahan memiliki skor tertinggi dengan persentase $43,33 \%$ dengan kategori sangat puas dan sapronak memiliki skor tertinggi dengan persentase 36,67\% dengan kategori sangat puas. Hal ini berarti bahwa variabel ketersediaan modal menjadi faktor pembatas dalam usaha ternak ayam broiler di Kecamatan Karangpawitan Kabupaten Garut. Menurut Rahardi (2003) modal merupakan sejumlah barang, jasa dan uang yang dimiliki untuk memulai sebuah langkah usaha di bidang peternakan. Perlu dicari peluang dan solusi agar peternak ayam broiler dapat memperoleh akses yang mudah terhadap permodalan. Modal merupakan hal yang sangat vital dalam sebuah bisnis atau perusahaan. Tanpa modal, bisnis tidak dapat berjalan sebagaimana mestinya. Selain modal finansial, modal yang dapat dijadikan untuk investasi dimasa depan adalah modal sosial (Suharto, 2007).

\section{Jaminan Pasar}

Analisis minat masyarakat terhadap usaha ternak ayam broiler dilihat berdasarkan variabel jaminan pasar diukur dengan menggunakan sub variabel: (1) pemasaran hasil budidaya, (2) arah penjualan, dan (3) ketersediaan bakul. Analisis minat masyarakat terhadap usaha ternak ayam broiler dengan berdasarkan variabel jaminan pasar dapat dilihat pada Gambar 2. 


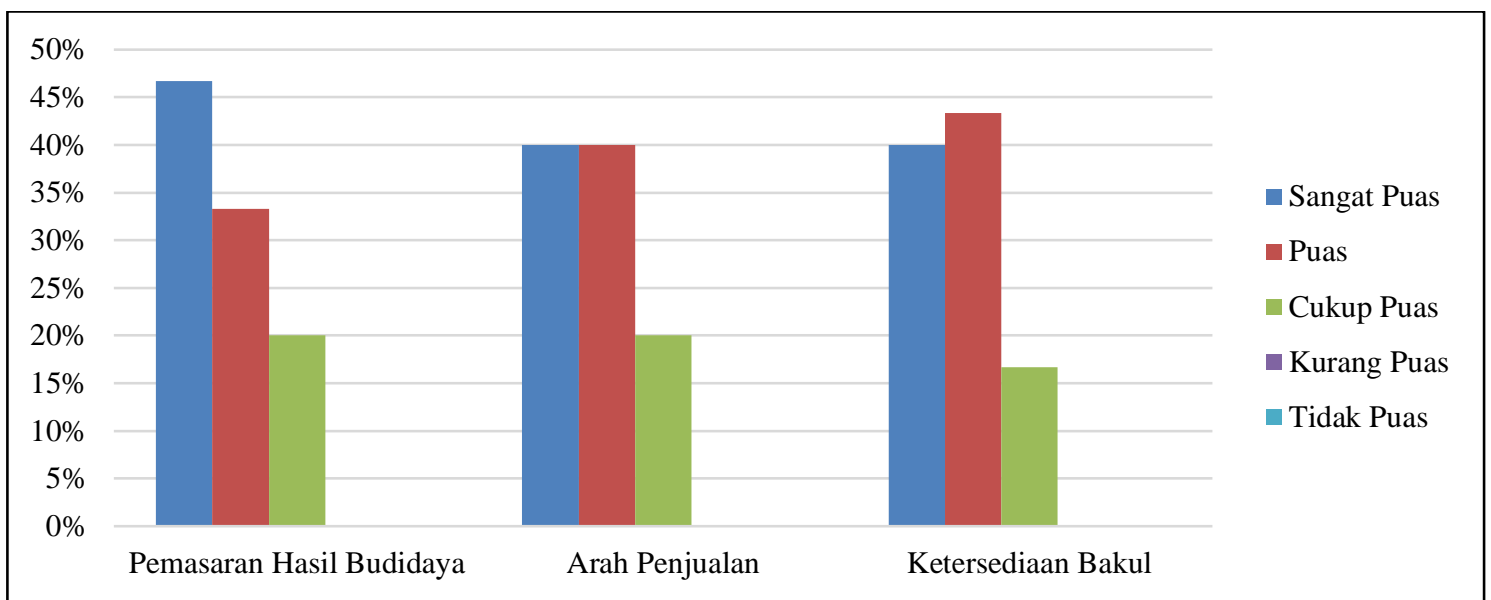

Gambar 2. Histogram Minat Masyarakat terhadap Usaha Ternak Ayam Broiler Berdasarkan Variabel Jaminan Pasar

Gambar 2 menunjukkan pemasaran hasil budidaya memiliki skor tertinggi dengan persentase 46,67\% dengan kategori sangat puas. Arah penjualan memiliki skor tertinggi dengan persentase $40,00 \%$ dengan kategori sangat puas dan puas, dan ketersediaan bakul memiliki skor tertinggi dengan persentase $43,33 \%$ dengan karegori puas. Hal ini menunjukkan bahwa variabel jaminan pasar bukan pembatas dalam usaha ternak ayam broiler di Kecamatan Karangpawitan Kabupaten Garut. Peternak tanpa kemitraan usaha memasarkan hasil usaha peternakannya rata-rata ke pasarpasar tradisional yang ada di sekitar tempat usahanya, hal ini didasari oleh faktor untuk menghemat biaya transportasi. Dalam kondisi normal, peternak tersebut akan mudah menjual ayam ras pedaging siap potong, tetapi dalam kondisi tertentu seperti terjadi tingkat harga rendah maka peternak akan mengalami kesulitan memasarkan ayam potongnya, sehingga biasa terjadi peternak menjual murah ayam ras pedaging siap potong, serta berbanding lurus dengan peternak mengalami kerugian yang tidak sedikit. Demikian pula jika menunggu perbaikan harga jual juga tidak banyak menolong, sebab pada kondisi tersebut ayam ras pedaging membutuhkan pakan yang menelan biaya yang cukup besar. Hal ini berarti pula adanya pengeluaran extra. Hal tersebut sesuai dengan penelitian yang dilakukan oleh Abidin (2002), bahwa dengan adanya program kemitraan dalam hal memasarkan hasil usaha peternakan itu dilakukan oleh perusahaan dan merupakan tanggung jawab perusahaan.

\section{Jaminan Harga}

Analisis minat masyarakat terhadap usaha ternak ayam broiler dilihat berdasarkan variabel jaminan harga diukur dengan menggunakan sub variabel: (1) harga sesuai kontrak, dan (2) bonus pasar. Analisis minat masyarakat terhadap usaha ternak ayam broiler deng an berdasarkan variabel jaminan harga dapat dilihat pada Gambar 3. 


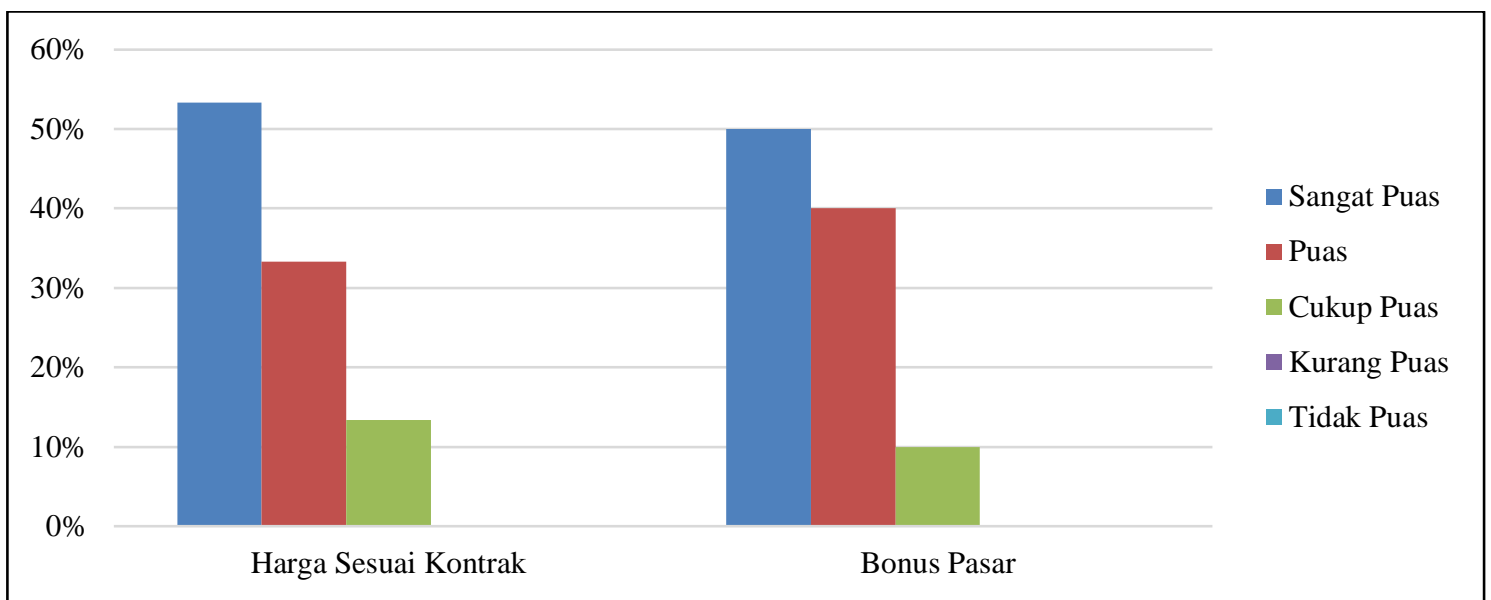

Gambar 3. Histogram Minat Masyarakat terhadap Usaha Ternak Ayam Broiler Berdasarkan Variabel Jaminan Harga

Gambar 3 menunjukkan harga sesuai kontrak memiliki skor tertinggi dengan persentase 53,33\% dengan kategori sangat puas dan bonus pasar memiliki skor tertinggi dengan persentase $50,00 \%$ dengan kategori sangat puas. Hal ini berarti bahwa variabel jaminan harga menjadi faktor penting dalam usaha ternak ayam broiler di Kecamatan Karangpawitan Kabupaten Garut. Kesepakatan harga dan bonus pasar menjadi salah satu pertimbangan khusus bagi peternak untuk bermitra dengan suatu perusahaan. Perlu adanya perhitungan khusus untuk menentukan besarnya kesepakatan harga. Perhitungan tersebut akan berakhir pada besaran laba yang akan diterima. Harga yang telah disepakati ini telah di perhitungankan dengan besarnya ongkos dan biaya yang dikeluarkan. Bonus pasar merupakan penawaran khusus dari suatu perusahaan kemitraan agar peternak dapat bermitra dengan perusahaan. Apabila tanpa adanya kesepakatan harga dan bonus pasar, suatu usaha tidak akan berjalan dengan efektif dan efisien. Hal tersebut sesuai dengan pendapat Elisabeth (2014), bahwa harga merupakan faktor utama yang dipertimbangkan dalam memilih produk atau jasa.

\section{Nilai Ekonomis}

Analisis minat masyarakat terhadap usaha ternak ayam broiler dilihat berdasarkan variabel nilai ekonomis diukur dengan menggunakan sub variabel: (1)manfaat beternak ayam broiler, dan (2) meningkatkan pendapatan. Analisis minat masyarakat terhadap usaha ternak ayam broiler dengan berdasarkan variabel nilai ekonomis dapat dilihat pada Gambar 4.

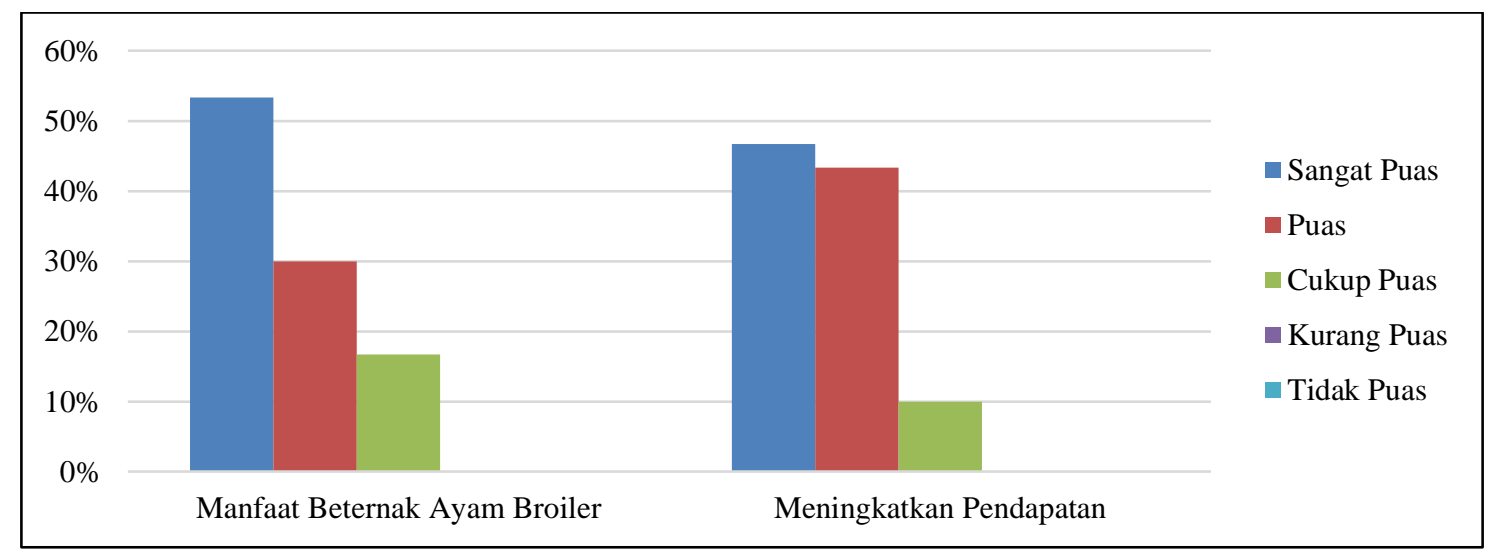

Gambar 4. Histogram Minat Masyarakat terhadap Usaha Ternak Ayam Broiler Berdasarkan Variabel Nilai Ekonomis 
Gambar 4 menunjukkan hasil dari analisis minat masyarakat terhadap variabel nilai ekonomis usaha ternak ayam broiler di Kecamatan Karangpawitan Kabupaten Garut didapatkan skor tertinggi pada sub variabel manfaat beternak ayam broiler dengan persentase 53,33\% dengan kategori sangat puas yang berarti bahwa beternak ayam broiler memberikan manfaat langsung bagi peternak. Sub variabel meningkatkan pendapatan mendapat skor tertinggi 43,37\% diperoleh pada kategori sangat puas yang berarti ternak ayam broiler menyebabkan bertambahnya pendapatan. Ayam broiler memiliki nilai ekonomis tinggi. Peternakan ayam broiler dalam usaha kecil dan besar mampu meningkatkan pendapatan masyarakat. Bahkan bagi peternakan kecil di pedesaan. Hal ini menunjukkan bahwa masyarakat memilih beternak ayam broiler karena memiliki manfaat secara ekonomis bagi kehidupan mereka. Hal tersebut seperti yang diungkapkan oleh Amrullah (2002), bahwa masyarakat yang memiliki tingkat pendapatan yang tinggi biasanya diikuti dengan meningkatnya kebutuhan-kebutuhan. Beternak ayam broiler sebenarnya banyak keuntungannya bila dibandingkan dengan kemungkinan kerugian yang diderita. Pemeliharaan ayam broiler tidak menuntut banyak persyaratan khusus dalam pemeliharaan, karena ayam broiler merupakan ternak yang mudah beradaptasi di setiap lingkungan tergantung pemeliharaannya dan tidak sulit dalam pemeliharaannya khususnya dalam pemberian pakan.

\section{$4 \quad$ Kesimpulan}

Berdasarkan hasil penelitian dapat ditarik kesimpulan bahwa faktor-faktor yang mempengaruhi minat masyarakat terhadap usaha ternak ayam broiler di Kecamatan Karangpawitan Kabupaten Garut adalah modal (puas); jaminan pasar (sangat puas); jaminan harga dan nilai ekonomis (sangat puas). Faktor yang paling berpengaruh terhadap minat masyarakat untuk usaha ternak ayam broiler adalah jaminan harga.

\section{$5 \quad$ Daftar Pustaka}

Abidin, Z. 2002. Meningkatkan Produktivitas Ayam Ras Pedaging. Agromedia Pustaka. Jakarta.

Amrullah. 2002. Keuangan Pertanian dan Pembiayaan Perusahaan Agribisnis. Gramedia Pustaka Utama. Jakarta.

Arifin, B. 2004. Analisis Ekonomi Pertanian Indonesia (An Analysis on Indonesian Agricultural Economics). Penerbit Buku Kompas. Jakarta.

Badan Pusat Statistik. 2018. Statistika Indonesia Tahun 2018. Badan Pusat Statistik. Jakarta.

Elisabeth. 2014. Analisis Faktor Pendorong Peternak Ayam Broiler Melakukan Kemitraan di Kecamatan Marusu Kabupaten Maros. Skripsi.

Rahardi, F. 2003. Agribisnis Peternakan. Penebar Swadaya. Jakarta.

Rudiyanto A A, 2014. Pola kemitraan koperasi sejahtera abadi dalam meningkatkan keuntungan petani cabai. Jurusan ekonomi pembangunan fakultas ekonomi Universitas Negeri Semarang. Journal of economics 7(2) : 100-202. 
Vol. 5; No. 1; Desember 2020

Halaman 98 - 105

Raharjo, Tri Weda. 2018. Pengembangan Ekonomi Masyarakat Melalui Penguatan Kemitraan Usaha UMKM, Koperasi dan Korporasi. Jakad Publishing. Surabaya.

Suharto, Edi. 2007. Kebijakan Sosial Sebagai Kebijakan Publik. Alfabeta. Bandung.

Windarsari, L. D. 2012. Kajian Usaha Peternakan Ayam Ras Pedaging di Kabupaten Karang Anyar: Membandingkan Antara Pola Kemitraan Dan Pola Mandiri. Jurnal Ilmu Pertanian dan Perikanan. 1 (1): 65-72. 